DOI 10.37882/2223-2982.2021.08.26

\title{
ФРАЗЕОЛОГИЗМЫ КАК СРЕДСТВО ЯЗЫКОВОЙ ОБЪЕКТИВАЦИИ КОНЦЕПТА УДАЧИ В РУССКОМ И ПОЛЬСКОМ ЯЗЫКАХ
}

\section{PHRASEOLOGICAL UNITS AS A MEANS OF LANGUAGE OBJECTIFICATION OF LUCK CONCEPT IN RUSSIAN AND POLISH LANGUAGES}

\section{E. Petrova}

Summary: This article deals with the analysis of phraseological units, which form the basis of language objectification of the concepts of luck and powodzenie in Russian and Polish cultures. Phraseological units contain figurative rather than direct meaning in their semantics. They reflect axiologically significant values for this or that linguocultural community. We consider the linguistic picture of the world as «a speculative construction, used by its creators to solve any theoretical or practical problems. It is a kind of tool. As applied to linguistics the picture of the world in any case should represent this or that way issued systematization of the plan of the contents of language» [4, p. 4]. One of the elements of the mosaic of the cultural image of the Russian and Polish ethnic groups is the concept of luck, consisting of the concepts luck and powodzenie.

Keywords: phraseology, semantics, axiological value, cultural image, semantic core.

\author{
Петрова Елена Владимировна \\ nреподаватель, ФГКВОУ ВО «Военный университет» \\ Министерства обороны Российской Федерации \\ madhyri@rambler.ru
}

Аннотация: Статья посвящена анализу фразеологических единиц, образующих фундамент языковой объективации концептов удача и powodzenie в русской и польской культурах. Фразеологизмам свойственно содержать в своей семантике не прямое, а переносное значение. В них отражены аксиологически значимые для той или иной лингвокультурной общности ценности. Языковая картина мира рассматривается нами как «умозрительное построение, используемое его создателями для решения каких-либо теоретических или практических задач. Это своего рода орудие. Применительно к лингвистике картина мира в любом случае должна представлять собой тем или иным образом оформленную систематизацию плана содержания языка» $[4$, c. 4].

Одним из элементов мозаики культурного образа русского и польского этносов является понятие удачи, складывающееся из концептов удача и powodzenie.

Ключевые слова: фразеологизм, семантика, аксиологическая ценность, культурный образ, семантическое ядро.

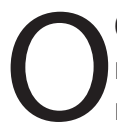

бъектом исследования в настоящей статье являются фразеологические единицы как концентрат переносного смысла понятий, которым их наделяют носители той или иной культуры. Исследование проводится на языковом материале русской и польской лингвокультур. Семантическим ядром исследуемых единиц выступает концепт удачи как аксиологически значимого для любой сферы жизни понятия.

В системе аксиологически важных ценностей с точки зрения менталитета и культуры особое значение имеет религия. Рассматриваемое нами понятие удачи тесным образом связано с верой, либо в случай (на авось) либо в Бога, Божье произволенье. В данном контексте удача является трансцендентным понятием. В нее можно верить, как в чудо. Можно молиться о везении, о благополучии, об удачном исходе какого-либо предприятия.

Представленные в настоящем исследовании фразеологические единицы и фразеологические сочетания обращены к трансцендентным понятиям. Тематика провидения пересекается с понятием неизвестности того, что человека ожидает в будущем, зависимости жизни от судьбоносных событий и воли случая. Рассмотрим основные лексемы, выражения и фразеологизмы, имеющие семантику характеристики деятеля с точки зрения отношения к удаче и способствующих удаче обстоятельств. Обратимся к анализу фразеосочетаний с семантикой удачи в сфере материальных благ и фразеосочетаний с семантикой надежды на удачу.

(1) «Родился в сорочке / рубашке» - „W czepku urodzony\| (букв. «рожденный в чепце») [14, s. 51]. Фразеологическая единица употребляется в ситуациях, когда человеку всегда сопутствует успех.

В польском языке находим следующую дефиницию. „Taki, któremu sprzyja szczęście, powodzenie, któremu we wszystkim się szczęści, id.: w czepku urodzony\| - «Тот, которому сопутствует счастье, везение, которому во всем везет, то же самое: в чепце родился» [6, s. 231].

Обратимся к языковому материалу, иллюстрирующему употребление приводимого фразеологизма в русском языке: «Ему удается все, за что бы он ни брался, вероятно, родился в сорочке» [lbid.]; «Есть люди, которые, как уверяли астрологи, явились на свет под счастливой звездой, или, как гласит народная пословица, родились в 
сорочке (П. Каратыгин. Записки)» [lbid.].

(2) «Родиться под счастливой звездой» - „Urodzony pod szczęśliwą gwiazdą|| [lbid., s. 705]. Приводимая ФЕ символизирует человека, которому всегда сопутствует удача.

Рассматриваемая пара ФЕ перекликается по смыслу с русскими и польскими лексемами и фразеосочетаниями. Ср.: баловень судьбы - 'ulubieniec losu', любимец судьбы - 'wybraniec', любимчик судьбы - 'ulubieniec fortuny /losu!' "Dziecko szczęściall (букв. «баловень судьбы, избранник / любимец фортуны / судьбы») [13, Т. 2, s. 470]. Если человек удачлив, успешно добивается важных для него целей, его социальный статус повышается, ведь он воспринимается как баловень/любимец судьбы.

(3) «Быть хозяином собственной жизни» - „Вус́ panem życia i śmiercill (букв. «править, распоряжаться своей жизнью самодержавно») [12, s. 643]. Человека успешного, благополучного, которому сопутствует удача, характеризует выражение хозяин жизни. Это значит, что такой человек всегда и во всем добивается положительного результата, у него все получается.

(4) «Фартовый человек» - „Fartowny facet\|[13, s. 883]. Прилагательное фартовый производно от лексемы фарт, синонимичной слову удача. «Большой толковый словарь русского языка» С.А. Кузнецова дает следующее толкование прилагательному фартовый. «1) Такой, которому везет, удачливый. Фартовый парень, мужик. $(\ldots) ; 2)$ Очень хороший, замечательный. (...) Фартовые девушки; 3) Озорной, лихой, склонный к мошенническим проделкам» [2, с. 1417]. Прилагательное фартовый может служить не только для характеристики людей, но и других вещей [Там же]. Другими словами, фартовый человек - это тот, которому всегда удается выйти сухим из воды. Приводимая ФЕ говорит о том, что кому-л. удалось выбраться из проблемных ситуаций, успешно справиться с возникшими проблемами, неудачами, в том числе в случае крупных неприятностей, в которых есть и доля своей вины [6, с. 192], а также о том, что кому-л. удалось при этом не замарать своего имени и избежать других последствий.

Приблизительным польским аналогом сочетания фартовый человек является fartowny facet - 'везучий парень'. Лексема fartowny дается с пометой «разг.» и означает везучего человека (но может встретиться и для определения других сущностей, не обозначающих людей). См., например, „Tobył dla mnie fartowny dzieńl - «Это был для меня фартовый день» [13, Т. 1, s. 883].

Фразеосочетания русского и польского языков чрезвычайно схожи семантически, однако различаются словообразовательной структурой: в русском языке фигу- рирует суффикс -овы, а в польском - суффикс -owny.

(5) «Иметь легкую руку» - „Ktoś ma dobrą (szczęśliwą) rękę\| [3, Т.2, с. 317]. Согласно «Словарю русского языка» под редакцией А.П. Евгеньевой, легкой рукой именуется: 1) тот, кто приносит удачу, счастье; 2) тот, кто удачно, счастливо начинает и ведет что-л., какое-л. дело. «Выражение иметь легкую руку является характеристикой субъекта - лица» [5, Т. 2, с. 169].

Адвербиальное словосочетание сделать что-либо с чье-либо легкой руки служит описанию ситуации, показывающей, каким образом что-то происходит, кто способствует происходящему [Там же].

В польском языке оборот ktoś ma dobra (szczęśliwa) rękę употребляется в тех случаях, когда кому-либо везет постоянно и любое предпринятое дело заканчивается успехом. Кроме того, житейская мудрость гласит о том, что помощь легкой руки может принести удачу невезучему человеку [3, Т. 2, с. 317].

(6) «Как (будто, словно, точно, что) сыр в масле кататься» - „Zycie jak w Madrycie\| (букв. «жизнь, как в Мадриде») [11, s. 266]. В русском языке метафорические образы сыра и масла ассоциируются с безбедной, материально благополучной жизнью [7, с. 196]. Значение фразеологического оборота заключается в том, что человеку благоволит удача, везет в жизни. Номинативной единице фразеологического пласта русского языка созвучен фразеологизм молочные реки и кисельные берега, соотносимый с привольной, обеспеченной жизнью $[7$, c. 389].

В польском языке находим речевой оборот żус́ nieumierać, выражающий наивысшую оценку условий жизни или ситуации, развивающейся наиболее благоприятным образом [10, s. 741].

(7) «Верить в свою счастливую звезду» - „Wierzyć w swoją gwiazdę\| (wswojeszczęście, wpomyślną przyszłość) $[12$, T. 2, s. 564].

В польском языке концепт удачи может быть выражен через такие лексемы, как gwiazda -'звезда', szczęście -'счастье' и словосочетание pomyślnaprzyszłośćd - 'удачное будущее'. При этом существительное pomyślność - 'удача' используется не всегда. Таким образом, польскими соответствиями лексемы удача русского языка, выступающими с глаголом wierzyć - 'верить', являются другие лексемы и их сочетания, но не pomyślność - 'удача' как таковая.

(8) «Удача / судьба улыбнулась» - „Los uśmiecha się do kogoś|| [9], [10].

Приводимые фразеологизмы исследуемой языковой 
пары коррелирует с друг с другом. Сочетаемость лексем в обороте с аналогичной семантикой показывает, что в польском языке понятия удачи и судьбы семантически связаны. Очевидно, что в польском языке понятие удачи формируется как результат персонификации понятия судьбы, но не понятия удачи в виде лексемы pomyślność 'удача', которая персонификации не подвержена.

(9) «Попасть в десятку» - „Trafić w dziesiątkę\| [11], [12]. Выражение обозначает ситуацию, когда человек из многих вариантов решения проблемы выбрал единственно верный, угадал, как можно выйти из затруднительного положения, как добиться успеха в сложившейся ситуации.

Проведенное исследование подводит нас к следующим выводам. Концепты удача и ротуślność в русском и польском языках манифестируются через комплекс языковых средств, приобретая определенные типологические характеристики, языковую динамику, активность и продуктивность в составе лексических и коммуникативных единиц с семантикой удачи. Тематика удачи изобилует устойчивыми словосочетаниями и фразеологизмами. Примеры фразеологизмов на основе русской лексемы удача демонстрируют многочисленные случаи персонификации. Удача является достаточно динамичной и мобильной сущностью, характеризующейся определенным непостоянством, о чем свидетельствуют обороты, в которых удача приходит и уходит. Подчеркнем, что в сфере фразеосочетаний русской лексеме удача не всегда соответствует базовая польская лексема pomyślność. В польском языке слову удача нередко соответствуют такие лексемы, как szczęście - 'счастье' и los - 'судьба', gwiazda - 'звезда'.

Группы лексических, фразеологических и коммуникативных единиц, формирующих концепт удачи русского языка и концепт pomyślność польского языка, выделяются по семантико-тематическому принципу в исследовательских целях на благо решения проблем сопоставительного анализа, перевода и лингводидактики. Сопоставительный анализ явился эффективным инструментом исследования понятия удачи и позволил наглядно выявить лингвоментальные средства формирования концептов удачи польского и русского языков. Понятие удачи, общее для носителей русского и польского языков, с одной стороны, обладает признаками универсальности, с другой стороны, проявляет ярко выраженные лингвоспецифичные черты.

\section{ЛИТЕРАТУРА}

1. Алпатов В.М. Что такое картины мира и как до них добраться // Язык. Константы. Переменные. Памяти Александра Евгеньевича Кибрика. СПб.: Алетейа, 2014. С. 11-21.

2. БТС - Большой толковый словарь русского языка / Гл. ред. и сост. С.А. Кузнецов. СПб.: Норинт, 1998. 1536 с.

3. Гюлумянц - Гюлумянц КМ. Польско-русский фразеологический словарь: в 2 т. Минск: Экономпресс, 2004. 688 с.

4. Корнилов 0.А. Языковые картины мира как производные национальных менталитетов. М.: Книжный дом «Университет», 2011. 350 c.

5. МАС - Словарь русского языка: В 4 т. / Под редакцией А.П. Евгеньевой. М.: Русский язык. 1981-1984.

6. УРПФС - Молотков А.И. Учебный русско-польский фразеологический словарь / А.И. Молотков, В. Цеслиньска. М.: Астрель; АСТ, 2001. 333 с.

7. ФСРЯ - Фразеологический словарь русского языка. 3-е изд., стереотип. / Сост. Л.А. Воинова, В.П. Жуков, А.И. Молотков, А.И. Федоров; Под ред. А.И. Молоткова. М.: Русский язык, 1978. 543 с.

8. IPR - Chlebda W., Gołubiewa A., Wawrzyńczyk J., Wielg T. Idiomypolsko-rosyjskie. Польско-русские идиомы. Warszawa: Wydawnictwo Naukowe PWN, 2003. 272 s.

9. NSS - Bogusławski A., Wawrzyńczyk J. Polszczyzna, jaką znamy. Nowa sonda słownikowa. Warszawa, 1993. $488 \mathrm{~s}$

10. PSF - BąbaS., Dziamska G., Liberek J. Podręczny słownik frazeologiczn yjęzyka polskiego. Warszawa: Wydawnictwo Naukowe PWN, 1995. 776 s.

11. SPBańko - Bańko M. Słownik porównań. Warszawa: Wydawnictwo Naukowe PWN, 2004. 268 s.

12. SFJP - Skorupka S. Słownik frazeologiczny języka polskiego: w2 t. Warszawa: Wiedza powszechna, 1967-1968.

13. USJP - Uniwersalny słownik języka polskiego:W4 t. / Pod. red. Stanisława Dubisza: Warszawa: Wydawnictwo Naukowe PWN, 2006.

14. WSFPRRP — Wielki słownik frazeologiczny polsko-rosyjski, rosyjsko-polski/ Red. naukowyJurijLukszyn, z-cared. Naukowego Wanda Zmarzer. Warszawa: Harald G Dictionaries, 1998.1102 s.

(c) Петрова Елена Владимировна (madhyri@rambler.ru).

Журнал «Современная наука: актуальные проблемы теории и практики» 